Eugeniusz Michalski

Koszalin University of Technology

\title{
MARKETING MANAGEMENT OF ENTERPRISE
}

The main goal of this article is to present how the new conception of marketing mix affects delivering value to customers and benefit an enterprise. The task of marketing management is to make the good and service available when a customer is ready to buy it. An enterprise needs timely, accurate and relevant information on customers, competitors and new socio-economic trends in the country and the world. The analysis of marketing management paradigm and creation of value based management were carry out. Next, the concept of marketing strategy and SWOT analysis were under consideration. Lastly, the impact of information technology on marketing management were described.

Key words: paradigm, values, strategy, SWOT, information technology

\section{Introduction}

This paper analyses the factors shaping marketing management of enterprise by applying descriptive, casual and comparative research. Work began to hypothesize that marketing management aims not only to gain profit but also to get customers, business partners the value, society well-being and protect the natural environment. The American Marketing Association describes marketing as an organizational function and set of processes for creating, communicating, and delivering value to customers and for managing customer relationship in ways that benefit the organization and its stakeholders [AMA 2015]. During an act of buying or selling individuals or groups obtain what they need and want through freely exchanging goods or services of value with each other. Exchange is a value-creating process because it leaves both parties better off or at least not worse off than before. To make successful exchanges an enterprise analyzes what customers expect from its offers. The process of negotiation leads to mutually acceptable terms. The enterprise without customers can't exists.

Coping with exchange processes calls for a considerable amount of work and skill. The enterprise should be better in creating, delivering and communicating value to target markets from the competitors. Original ideas about competition between domestic and foreign enterprises have gained great economic significance recently. Products have been design not only for target and niche markets, but more often for individual customers. General marketing's role is to deliver a higher standard of living.

An enterprise should be competently managing and well-run. Decision-maker have many demands on broad and sound knowledge, acquire the latest news and improve technological and marketing skills. Enterprises now know that marketing is done not only by marketers and customer support personnel but every employee has an impact on the customer and must see the customer as the source of enterprise's prosperity. More emphasis is also being placed on the management of new-product 
realization, customer's acquisition and retention, and orders fulfilment. In addition to monitoring a changing environment, markers want information to help interpret past performance as well as plan future activities [Roy 2014].

Discovering a customer insight and understanding its implication can often lead to a successful product launch or spur the growth. Good marketing research is characterized by creativity, multiple scientific methods, accurate monitoring, cost benefit analysis, healthy skepticism and ethical focus. It's get to know hidden, even underlying needs and imagination of customers. Very important tasks of producer and middleman are to stimulate a level, structure and fluctuation for demand. Customers can easer compare offers, prices and substitute for products by Internet. Middlemen increase in strength through combine with producers into marketing network.

\section{New aspects of marketing mix}

In marketing theory and practice are widen and increased knowledge about marketing mix. Apart from goods, services and ideas new designation for product have come such as experience, image, events, information, place and non-profit organization [Armstrong et al. 2015]. Marketing mix strategy directs to market target consists of four parts: an offer (goods, service, and price) information (advertising, sales promotion, sales force, public relation, direct marketing), distribution channels and target markets. The enterprise can change price and medium of information during every phase marketing activity in short term. New-product development and modification of distribution channels require a long period of time.

Experience refers to past events, knowledge and feelings that make up customer's life or character. By orchestrating several goods and services, an enterprise can create and stage market experiences. Customer experiences are feeling of joy during visiting an exhibition, trade shows, artistic stage performance, musical entertainment and celebrating enterprise anniversary. Sporting events are promoted to both enterprises and fans. There are professionals who work out an event and make sure it comes off perfectly.

The image of a person, group, product or enterprise is the way that they appear to customers. The enterprise establishes the product's character and value proposition in highlighted and distinctive way. Image should be diffused in ads, annual reports, brochures, catalogs packaging, enterprise stationary and business cards. It could create image of politician, actor, comedian, musician, physician and lawyer. Image can be associate also with the highlighting place, region, country place for active leisure and entertainment.

Aside from consumer and industrial products gain quite significance meaning nonprofit and governmental markets. Nonprofit organizations such as churches, schools, universities, charitable organizations government agency need to be price carefully because they have limited purchasing power. Lower prices affect the features and quality that seller can built into the offering. Much government purchasing calls for bids, with the lowest bid being favored. There are promoting more frequently country, recreational centers, theaters, restaurant and parks. It is extend market sphere, because aside from shops purchase can be done through internet. Customers can order products from various directions of the world, a plane, bus or train. 
Meta market comes into existence. It is a cluster of complementary products and services that are closely related into minds of customers but are spread across a diverse set of enterprises [Meta Markets 2015]. The automobile meta market consists of automobile manufactures, new car and use car dealers, financing and insurance companies, mechanics, spare parts dealers, service shops, auto magazines, classified auto ads in newspapers, and auto sites in internet. Other example are the home ownership market, baby care market, and the wedding market.

Information can be also marked as a product. Schools, universities, books, professional journals and computer worlds distributed knowledge, competence and expertise. Even enterprises that sell physical goods attempt to add value through the use of information. Technological advances in transportation, shipping and communication have made easier for enterprises to market in others countries and readily to customers to buy products from other countries. Information can be appraise against a background of sources or impact on promotion. An enterprise can get to know some unknown reason behind fall the demand for the product. The demand can be hidden, under fluctuation or come to an end. The customers are on alert for buying unhealthy products or harmful to natural environment.

\section{The concept of marketing management}

Marketing management is the art and science of choosing target markets and getting, keeping and growing customers through creating, delivering and communicating superior value. The first task facing an enterprise is to identify its potential long-run opportunities given to its market experience and core competencies. To understand what is happening inside and outside the enterprise needs a reliable marketing information system, it will closely monitor outside environment [Kotler, Keller 2006]. Marketing research is an indispensable system for assessing customer wants and behavior and actual and potential market size.

The enterprise macro environment consists of demographic, economic, physical, technological, political, legal and social-cultural forces that affect sales and profits. Microenvironment encompasses all the players who affect its ability to sells products - suppliers, intermediaries, customers, banks and competitors. To transform marketing strategy into programs, managers must make decisions on marketing expenditures, activities and allocation of employs.

Undertaken marketing decisions can be gathered and expressed in paradigm of marketing management. The paradigm present in table 1 , like any other model, contains simplification of real marketing management. Six characteristics make up the paradigm: knowledge, know-how, motivation, conditions, responsibility and courage [Michalski 2014].

Knowledge is a familiarity, awareness or understanding facts, information, descriptions or skills, which are acquired through education and experience by a decision-maker. Knowledge obliges with identify the situation on the market, describe criterion for choosing and assessment of the marketing decision, generate option for solving and assess the effects. In paradigm can be set apart following distinctive features, which are essential to make the best use of knowledge: know-how, motivation, conditions, responsibility and courage. 
Know-how is the ability or skill to application of knowledge, methods or techniques for doing something, especially something practical. It is commercial and saleable knowledge of how to make particular marketing decision. Benchmarking provides valuable context, helping to set meaningful target markets, gain insight into trends occurring across business environments and find out how successfully competing.

Motivation is the willingness to exert high levels of effort to reach enterprise goals, conditioned by the ability to satisfy customer's desires and needs and employ's actions. A motive is what prompts the decision-makers to act in a certain way or at least develop an inclination for specific behavior favorable for customers.

Table 1. Paradigm of marketing management

\begin{tabular}{|c|c|}
\hline Characteristics & Distinctive features \\
\hline Knowledge & $\begin{array}{l}\begin{array}{l}\text { Knowledge acquire during the studies, data-gathering and analysis of } \\
\text { marketing research findings, }\end{array} \\
\text { which facilitates election and implementation of marketing decisions, challenge } \\
\text { and throw down the } \\
\text { competitors. }\end{array}$ \\
\hline Know-how & $\begin{array}{l}\text { The ability to make good use of employ's competence, develop their skills from } \\
\text { own and competitors } \\
\text { successes or failures. }\end{array}$ \\
\hline Motivation & $\begin{array}{l}\text { Initiate new stimulus to influence on employ attitude towards activities and } \\
\text { customers; that be } \\
\text { inclined to initiatives, the entrepreneurial spirit and innovation. }\end{array}$ \\
\hline Conditions & $\begin{array}{l}\text { Create favorable atmosphere for taking effective decisions, implement modern } \\
\text { information technology, } \\
\text { remove barriers and restrictions hinder progress and sensible manage marketing } \\
\text { activities. }\end{array}$ \\
\hline Responsibility & $\begin{array}{l}\text { Responsibility for obey the low and business ethics; contribute to the well-being } \\
\text { society, environmental } \\
\text { protection and abandon unfair competition. }\end{array}$ \\
\hline Courage & $\begin{array}{l}\text { Confident and conscious support and insist on the realization of the appropriate } \\
\text { marketing decision, take } \\
\text { sometimes risk despite the shortcomings. }\end{array}$ \\
\hline
\end{tabular}

Source: Own elaborate

Conditions are a particular state of situation with respect to external or existing in the enterprise circumstances. It is something that supports or restricts marketing activities. The conditions to make the best use of marketing knowledge and know-how can be considered on global, international, domestic and local levels.

The attribute of marketing activity is to obey legal norms and business and professional ethics. An enterprise holds responsible for every good or bad deeds of employs. It must balance of shareholders, employs, customers, suppliers and ecological interests. An enterprise can apply four approaches to marketing responsibility awareness: negation, defense, taken on an obligation and prevention harmful business activity.

Courage is the quality to have the confidence to do what marketing decisionmaker believes is right, even though may be afraid or other people may not agree or approve. Conformity is the act of matching attitudes, beliefs, and behaviors to group 
norms. Tendency to conform occurs in groups of employs and may result from subtle unconscious influences, or direct and overt pressure. Group pressure may take different forms, for example bullying, persuasion, and teasing or criticism. Courage is sometimes suppresses by inconsistent economic system and or impractical and incoherent legal articles.

Values based marketing management is an approach in which managers establish, promote and practice an enterprise's shared values. An enterprise's values reflect what is stands for and what it believes in. The values originate from enterprise's culture and influence the way in which employees and customers behave [Michalski 2014]. The enterprise gain profitability through excellence, respect for individual, involved citizenship, dedication to fairness and integrity, and existing for the customers. Values based marketing management can be expressed by acronym PRIDE, which is put forward in table 2 .

Table 2. Value based marketing management

\begin{tabular}{|l|l|}
\hline Profitability & $\begin{array}{l}\text { Cause-related marketing links business profit to customers' } \\
\text { concern and improve } \\
\text { at the same time. }\end{array}$ \\
\hline Respect & $\begin{array}{l}\text { Recognition for every employ, customer, supplier, and other } \\
\text { participant in market; increases the authority and responsibility of } \\
\text { those closest to customers. }\end{array}$ \\
\hline Involvement & $\begin{array}{l}\text { Employs are engaged in finding and solving essential issues of } \\
\text { development an enterprise; increase share in the market and profit; } \\
\text { strive after perfection. }\end{array}$ \\
\hline Dedication & $\begin{array}{l}\text { Employs are assessed by directness, openness to influence, } \\
\text { commitment to success, willingness } \\
\text { to acknowledge own contributions to problems, teamwork and } \\
\text { trust. }\end{array}$ \\
\hline Existence & $\begin{array}{l}\text { Provide an enterprise continuity in economic crisis a stability } \\
\text { development in turbulent environment. }\end{array}$ \\
\hline
\end{tabular}

The marketing activities will be successful if they deliver value and satisfaction to the target customers. Value reflects the perceived tangible and intangible benefits and costs to customers. Value can be seen primarily as a combination of quality, service, and price. It is called customer value triad. Value increases with quality and service and decreases with price, although other factors can also play an important role.

Currently marketing can be seen as the identification, creation, communication, delivery and monitoring of customer value. Satisfaction reflects customer's comparative judgments resulting from a product's perceived performance (or outcome) in relation to his expectation. If the performance falls short of expectations, the customer is dissatisfied and disappointed. If performance matches the expectations the customer is satisfied. If the performance exceeds expectations, the customer is highly satisfied and delighted. 


\section{Marketing strategyplanning}

The first task facing the managers are to develop marketing strategy which identify its potential opportunities given their market experience and core competition. Next they must develop concrete marketing plans and going forward tactics. Marketing information system and marketing research are reliable and indispensable tools for assessing customer wants and behavior, and actual and potential market size. To transform strategy into programs, managers must make decision on marketing expenditures, activities and resources allocation.

An enterprise must consider the strategies how to create value for its target markets, and develop strong, profitable and long term relationship with customers [Michalski 2012]. Strategy choices on whether the enterprise is a market leader, challenger, follower or nicher. Marketers must also pay close attention to competitors, anticipating competitors' moves and knowing how to react quickly and decisively against issue challenges.

At the heart of marketing program are goods - the enterprise's tangible offering to the market, which includes quality, design, features, and packaging. As a part of offering may be provided various support service which can guarantee competitive advantage in market place. A critical marketing decision relates to price. It has to decide on wholesale, and retail price, discounts, allowances and credit terms. An enterprise must identify, recruit and link various marketing facilitators to supply its goods and services efficiently to the target markets.

Marketing communications activities are means by which an enterprise attempts to inform, persuade and remind customers, directly or indirectly, about its offerings. An enterprise can develop an integrated communication program consisting of advertising, sales promotion, evens, public relations and lines of personal communication in the form of direct and interactive promotion.

Finally an enterprise must organize marketing resources and implement and control the marketing strategy plans. Evaluation and control are necessary to understand the efficiency and effectiveness of marketing activities and how both could be improved. To ensure that the proper activates are selected and executed, strategic planning is paramount and calls for action in three key areas:

- managing an enterprise's business as an investment portfolio,

- assessing each business's strength by considering the market growth rate and enterprise's position and fit in the market,

- establishing a strategy for achieving its long-run objectives.

The strategic marketing plan lays out the target markets and value propositions that be offered, based on an analysis of the best market opportunities. Assessing growth opportunists involves planning new businesses, downsizing, or terminating older business. If there is a gap between future desired sales and project sales, management will develop or acquire new business to fill it.

The enterprise first considers whether it could gain more market share with its current products in its current markets (market-penetration strategy). Next it considers whether it can find or develop new markets for its current products (market-development strategy). Then it considers whether it can develop new products of potential interest to its current markets (product development strategy). Later it would also review 
opportunities to develop new products for new market (diversification strategy). By examining these intensive growth strategies, management may discover several ways to grow. Still, that growth may not be enough so the management must also look for integrative growth opportunities [Bartlett and Beamish 2011].

An enterprise's sales and profits may be increased through backward, forward or horizontal integration with its partners. The industrial enterprise might acquire one or more of its suppliers to gain more control or generate more profit (backward integration) It may acquire some wholesalers or retailers, especially if they are highly profitable (forward integration). Finally, it may acquire one or more competitors, provided that the government does not bare this move (horizontal integration). However, these new sources may still not deliver the desired sales volume. In that case, the enterprise must consider diversification.

Diversification growth makes sense when good opportunities can be found outside the present businesses. A good opportunity is one in which the industry is highly attractive and the enterprise has the right mix of business strengths to be successful. Several types of diversification is possible.

The industrial enterprise could seek new products that have technological or marketing synergies with existing product lines, even though the products themselves may appeal to a different group of customers (concentric strategy). It might search for new product lines, even though the new products are technologically unrelated to its current product line (horizontal strategy). The enterprise might also seek new businesses that have no relationship to its current technology, product or markets (conglomerate strategy). Managers should focus on growth opportunities, and not fritter away energy and resources trying to salvage hemorrhaging businesses.

The overall evaluation of an enterprise's strengths, weaknesses, opportunities, and threats is called SWOT analysis (Kotler and Keller 2006]. It involves monitoring the external and internal marketing environment. External environment consists of macro environment forces (demographic-economic, natural, technological, political-legal, and social-cultural) and microenvironment partners (customers, competitors, suppliers, distributors, dealers) that affect its ability to earn profits and to identify the associated opportunities and threats. Marketing opportunities is an area of customer needs and interests in which there is a high probability that an enterprise can profitably satisfy that needs. There are two main sources of market opportunities: to supply something that is in short supply or to supply an existing good or service in a new or superior way.

The possible improvements can be uncovered by asking customers for their suggestions (problem detection method); by asking customers to imagine an ideal version of the good or service, and by asking consumers to chart their steps in acquiring, using, and disposing of a product (consumption chain method). The latest sources often leads to new good or service.

An environmental threat is a challenge posed by an unfavorable trend or development that would lead, in absence of defensive marketing action, to lower sales or profit [Stiglitz 2002]. Threats should be classified according to seriousness and probability of occurrence.

Once management has identified the major threats and opportunities facing an enterprise, it can characterize that enterprise's overall attractiveness. It is one thing to 
find attractive opportunities and another to be able to take advantage of them. Each enterprise needs to evaluate its strength and weaknesses by checking:

- Marketing: enterprise reputation, market share, customer satisfaction customer retention, good quality, service quality, pricing effectiveness, promotion effectiveness, sales force effectiveness, innovation effectiveness and geographical coverage;

- Finance: cost, availability of capital, cash flow, financial stability;

- Manufacturing: facilities, economic of scale, capacity, able-dedicated workforce, ability to produce on time, technical manufacturing skill;

- Management: visionary and capable leadership, dedicated employees, entrepreneurial orientation and flexible or responsible activities.

M. Porter has proposed three generic strategies: overall cost leadership, differentiation and focus [Kotler and Keller 2006]. The enterprise can work to achieve the lowest production and distribution costs so that it can price lower than its competitors and win large market share. The problem with this strategy is that other enterprises will usually compete with still lower costs and hurt the enterprise that rested its whole future cost. The enterprise might concentrate on achieving superior performance in important customer benefit area, valued by a large part of the market. It cultivates those strengths that will contribute to the intendent differentiation. The enterprise can focused on one or more narrow market segments. It gets to know these segments intimately and pursues either cost leadership or differentiation within target market.

Enterprises might also discover that they need strategic partners if they hope to be effective. Enter in foreign market may require the enterprise to license its product, form joint venture with local enterprise or buy from local suppliers to meet domestic requirements [Bartlett Beamish 2011]. Many strategic take the form of marketing alliances fall into four categories:

- Good or service alliances - one enterprise licenses another to produce its product or two enterprises jointly market their complementary products or a new product.

- Promotion alliances - one enterprise agrees to carry a promotion for another enterprise's good or service.

- Logistics alliances - one enterprise offers logistical services for another enterprise's product.

- Pricing collaborations - one or more enterprises join in a special pricing collaboration (hotel and rental car enterprises offer mutual price discounts).

Enterprises need to give creative thought to finding partners that might complement their strengths and offset their weaknesses. Well-manages alliances allow enterprises to obtain a greater sales impact at less cost. To keep their strategic alliances thriving, enterprises have begun to develop new organizational structures to support them and have come to view the ability to form and manage partnerships as core skills.

\section{Impact of information technology on management}

Information technology (IT) is the application of computers and telecommunications equipment to store, retrieve, transmit and manipulate data, often in the context of an enterprise. The term is commonly used as a synonym for computers and computer 
networks, but it also encompasses other information distribution technologies such as television and telephones. IT marketing professionals possess the right combination of knowledge and practical expertise to take care of both an enterprise's information technology infrastructure and the employs who use it [Daft and Armstrong, 2015].There are software systems concern reliability, security, usability and effectiveness for marketing intended purpose. IT jobs include computer programming, network administration, computer engineering, Web development, technical support, and many other related occupations. Since we live in the "information age," information technology has become a part of our everyday lives.

IT concerns with all aspects of managing and processing information. It actually includes layers of all systems within an enterprise - from the physical hardware to the operating systems, applications, databases, storage and servers. Telecommunication technologies, including internet and business phones are also part of an IT infrastructure.

Electronic-marketing (E-marketing) is the application of information and communication technologies (ICT) in support of all the activities of enterprise. Emarketing constitutes the exchange of goods and services between businesses, groups and individuals and can be seen recently as one of the essential activities of any enterprise [Zeithamlel al. 2009]. It focuses on the external activities and relationships to inform customers, promote, and sell goods and services over internet network. Emarketing includes e-commerce and also covers internal processes such as production, inventory management, product development, risk management, finance and human resources. E-marketing strategy is more complex, focused also on cost savings and improvements in efficiency and productivity.

Electronic commerce (E-commerce) is trading in goods using computer networks, such as mobile commerce, electronic funds transfer, supply chain management, online transaction processing, electronic data interchange (EDI), inventory management systems, and automated data collection systems. It typically uses the World Wide Web for at least one part of the transaction's life cycle, although it may also use other technologies such as e-mail. It may employ online shopping web sites for retail sales direct to consumers, providing or participating in process third-party business-toconsumer (B2C) or consumer-to-consumer (C2C) sales and business (B2B) buying and selling or electronic.

E-commerce is gathering and using demographic data through web contacts and social media. It can establish customers by e-mail or fax and engaging in retail for launching new products. E-commerce covers outward-facing processes that touch customers, suppliers and external partners, including sales, marketing, order taking, delivery, customer service, purchasing of raw materials and supplies for production and procurement of indirect operating-expense items, such as office supplies. It involves new business models and the potential to gain new revenue or lose some existing revenue to new competitors.

B2B refers to a situation where one enterprise makes a commercial transaction with another. This occurs when an enterprise is sourcing materials for their production process, needs the services of another enterprise for operational reasons (e.g. an accountancy firm to audit its finance), re-sells goods and services produced by others manufacturers. Contrasting terms is business-to-government (B2G). B2C focus on retail transactions. 
The overall volume of $\mathrm{B} 2 \mathrm{~B}$ transactions is much higher than the volume of $\mathrm{B} 2 \mathrm{C}$ transactions. The primary reason for this is that in a typical supply chain there will be many transactions involving sub components or raw materials, and only one $\mathrm{B} 2 \mathrm{C}$ transaction, specifically sale of the finished product to the end customer. For example, an automobile manufacturer makes several B2B transactions such as buying tires, glass for windscreens, and rubber hoses for its vehicles. The final transaction, a finished vehicle sold to the consumer, is a single (B2C) transaction.

B2B marketing techniques rely on the same basic principles as consumer marketing, but are executed in a unique way. While consumers choose products based not only on price but on popularity, status, and other emotional triggers, B2B buyers make decisions on price and potential profit. B2B involves three types of integration:

- vertical integration of front-end Web site applications to existing transaction systems;

- cross-business integration of a company with Web sites of customers, suppliers or intermediaries such as Web-based marketplaces;

- integration of technology with modestly redesigned processes for order handling, purchasing or customer service.

Business-to-consumer activity exists both online and offline but the acronym $\mathrm{B} 2 \mathrm{C}$ has primarily been used to describe the online variety. B2C play a large role in the rapid development of free online services and discounted shopping, spurring adoption of the new medium. The digital revolution has created a whole new set of capabilities to consumers and enterprises. Consumers today can easier compere competitors prices and product attributes, exchange information and opinions. They can get answers on the internet without drive to stores and access online books, medical information, move ratings, consumer opinion and reports and other countless information sources. They can place orders from home, office or mobile 24 hours a day, 7 days a week, and the orders will be delivered to their home or office quickly.

The technological progress of information lead to more accurate levels of production, more targeted communications and more relevant pricing. Customers can even name the price they want to pay for a product. Middlemen aggregating their purchases can join with others to achieve deeper volume discounts. Customers can order goods almost from anywhere in the world, which help them bypass country with very limited local offerings and achieve great savings.

\section{Conclusion}

The article widened and increased knowledge about new marketing mix and comprised the strategies how to create value for target markets, and develop strong, profitable and long term relationship with customers. The hypothesis that marketing management aims not only to gain profit but also to get customers, business partners and society the value and protect the natural environment have been proven. Author's propose for the marketing management paradigm is made up of six characteristics: knowledge, knowhow, motivation, conditions, responsibility and courage.

New marketing mix, directs to market targets, consists of four parts: an offer, information, distribution channels and markets. New designation for product are such as experience, image, events, information, places and non-profit organizations. Values 
based marketing management established, promoted and practiced an enterprise's shared values, which originate from its culture and influence the way in which employees and customers behave. It should be highly recommended for industrial enterprises, middlemen, wholesalers as well as retailers.

In the article has been proved how an enterprise considered the strategies to create value for its target markets and develop strong profitable, long term relationship with customers. The marketing strategic plan lays out the target markets and value propositions that be offered and based on an analysis of the market opportunities. An enterprise's sales and profits increased through backward, forward or horizontal integration with its partners. Porter's proposal of three generic strategies: overall cost leadership, differentiation and focus plays a significant role in marketing management. Enterprises needed to give creative thought to finding partners that might complement their strengths and offset their weaknesses.

Electronic-marketing (E-marketing) not only support of all the activities of enterprise but also creates novelty value of enterprise's marketing management. Planning and managing an enterprise's IT infrastructure is a difficult and complex job that requires a solid foundation in applied computing as well as management and professional skills. Bigger and bigger application find in electronic commerce (Ecommerce) that traded in goods using computer networks, such as mobile commerce, electronic funds transfer, supply chain management, online transaction processing, electronic data interchange, inventory management systems, and automated data collection systems - typically uses the World Wide Web. The technological progress of information lead to more accurate levels of production, more targeted communications and more relevant pricing.

The outcomes of the inquiry show how complex are todays marketing management of enterprise and proved importance of new aspects of marketing mix, created marketing strategy and role of information technology for made marketing decisions.

\section{References}

AMA (2015), https://www.ama.org/AboutAMA/Pages/Definition-of-Marketing.aspx (10.30.2015) Armstrong G., Kotler Po., Trifts V., Buchwitz L. A. (2015), Marketing. An Introduction, Pearson Prentice Hall, Toronto, 5

Bartlett Ch. A., Beamish P.W. , (2011) Transnational Management, McGraw Hill, New York, 434, 511-512

Daft R. L., Armstrong A., (2015) Organization Theory and Design, NELSON Education, Toronto, 253 Kotler Ph., Keller K. L., (2006), Marketing Management, Pearson Prentice Hall, New Jersey, 56, 78

Meta Markets, 2015, http://www.marketing91.com/meta-markets/ (10.30.2015)

Michalski E., 2015, Zarządzanie przedsiębiorstwem, Wydawnictwo Naukowe PWN, Warszawa, 35,63

Michalski E., 2012, Marketing, Wydawnictwo Naukowe PWN, Warszawa, 451-453

Roy E. (2014), http://www.tradeready.ca/2014/fittskills-refresher/six-steps-creating-clear-usefultrade-research-objectives/ (12.11.2014)

Stiglitz J. E., (2002), Globalization and Its Discontents, W. W. Norton, New York, 36

Zeithaml V. A, Bitter M. J., Gremler D. D., (2009), Services Marketing, McGraw Hill, Boston, 353 


\section{Zarządzanie marketingowe przedsiębiorstwem}

\section{Streszczenie}

Głównym celem artykułu jest przedstawienie jak nowa koncepcja marketingu mix wpływa na dostarczanie wartości dla nabywców i przynosi korzyści przedsiębiorstwu. Zadaniem zarządzania marketingowego jest udostepnienie dóbr i usług nabywcom wtedy kiedy są gotowi do zakupu. Przedsiębiorstwo potrzebuje trafne i aktualne informacje o nabywcach, konkurentach i nowych trendach rozwoju społeczno-gospodarczego w kraju i na świecie. Analizie poddano paradygmat zarzadzania marketingowego i proces tworzenia zarzadzania marketingowego opartego na wartościach. Następnie rozpatrzono koncepcje strategii marketingowej i analizę SWOT. Na końcu omówiono wpływ technologii informacyjnej na zarzadzanie marketingowe.

Słowa kluczowe: paradygmat, wartości, strategia, SWOT, technologia informacyjna

Informacje o autorze:

prof. zw. dr hab. Eugeniusz Michalski

Department of Management,

Koszalin University of Technology,

E. Kwiatkowskiego 6e, 74343 Koszalin, Poland, e-mail:

e-mail: e_michalski@hotmail.com 